\title{
'Paying for the Emergency by displacing the settlers': global coffee and rural restructuring in late colonial Kenya ${ }^{1}$
}

\author{
David Hyde \\ School of Social Sciences, \\ University of East London, \\ 4-6 University Way, \\ London R16 2RD, \\ UK \\ E-mail: d.hyde@uel.ac.uk.
}

\begin{abstract}
Coffee production in Kenya entered into a phase of decline from the mid-1950s. As large producers, notably Brazil and Columbia, continued to increase their output, there arose intense struggles amongst global competitors for larger slices of a contracting market. The prospect of an economic catastrophe, following the release of Brazil's surplus stocks, preoccupied Kenya's colonial government. The latter was dependent on tax revenues derived from coffee sales, and was less able to support the settler dominated industry in face of the increased costs incurred by the Mau Mau Emergency after 1952. This left European settlers exposed, with many barely able to recover their costs of production. What began as a counter-insurgency strategy, by allowing an elite of African farmers to grow Arabica coffee, a privilege formerly reserved to settlers, was enlarged and accelerated in response to unrelenting global market pressures. These compelled the colonial government to beckon low cost African farmers into coffee production, in a bid to save its tax base and ensure the survival of the coffee sector. Even though the Coffee Marketing Board confiscated much of their income, African farmers proved well able to rally family labour and achieve surpluses. Rationalization of production, and the re-organization of the commodity chain to maintain high quality at lower cost, were decisive in both reconfiguring the economic and social relationships that underpinned Kenya's independence in 1963, and in securing the country's place on the world market. The aim here is to explain the crisis, and its grip on Kenya's economy during the transition to independence and beyond.
\end{abstract}

\footnotetext{
${ }^{1}$ The author welcomes responses to this article, and would like to thank the Henry Chapman Fellowship (Institute of Commonwealth Studies, University of London) and the University of East London for making the research possible through funding and leave respectively, the two peer reviewers for their invaluable appraisals, and Jonathan Curry-Machado, and colleagues of the Commodities of Empire Project for their encouragement.
} 


\section{The global crisis, 'Africanisation' and the restructuring of Kenya's coffee industry}

The post-1945 boom brought a period of lusty growth for Kenya's economy, with an overall growth rate of 13\% a year between 1947 and $1954 .^{2}$ The colony's agricultural exports, the great bulk of which came from European estates and plantations, were crucial to this process, and Kenya's plantation economy, founded upon coffee, tea, sisal and pyrethrum, aided the British economy in its post-war recovery phase. As with the expanded resource exploitation of Britain's other African colonies, the systematic large-scale production of export crops was accelerated to enable Britain to repay loans and credits to the USA through sales in dollar earning markets. The increased export earnings of these crops was largely a function of the rapid rise of world market prices as demand kept well ahead of supply. After 1950, the Korean War, coinciding with drought and frost in Brazil, caused a severe depletion of global stocks, and brought world coffee prices to a peak in 1955. Coffee producers around the world responded with a substantial increase in planting, with East African producers expanding their output to approximately 6\% of the world's coffee production.

Excessive planting during the boom years led to 'massive overproduction' ${ }^{3}$, moving the world market into a prolonged period of slump. Newly planted trees begin to bear in two to four years, if planted as seedlings, and four to five years if planted from seed, while the productive life of the trees can be thirty years or more, depending on variety, climate and husbandry practices. Prices thus fell drastically in the late 1950s, and the crisis deepened, as most producers in the world continued to increase output, in an attempt to compensate for falling prices. This led to a real prospect of economic catastrophe, were the dominant market players, Brazil and Columbia, to release their cumulative reserves onto the world market. A meltdown following such a move stood to substantially devalue the Kenyan economy, putting thousands of acres out of production, and plunging the country into deep recession during its transition to independence, gained in 1963. The spectre of the 1930s depression haunted officials and European settlers. The general downturn in prices of primary commodities undermined the role of Britain's colonies for the Sterling Area, as they began to run deficits in commercial

\footnotetext{
2 International Bank for Reconstruction and Development, The Economic Development of Kenya, Baltimore: IBRD, 1963, p.340.

${ }^{3}$ Benoitt Daviron and Stefano Ponte, The Coffee Paradox: global markets, commodity trade and the elusive promise of development, London: Zed Books, 2005, p.86.
} 
relations with the USA. In Kenya, the turnaround also threatened to downsize the budgetary resources of the state, undermining the colony's fiscal self-sufficiency. This problem was compounded by the government's debt burden, which mounted faster than its ability fund the colonial war against the Mau Mau movement. Between 1952 and 1959, at least £55 million were directly spent on containing the insurgency, quite apart from a wide range of invisible costs involved. ${ }^{4}$

Kenya's economy took an overall turn for the worse in 1957, when it suffered a $13 \%$ reduction in trade during the first nine months, with the 'bulk of the fall' attributed to coffee. ${ }^{5}$ Even though the 1956-7 crop fetched, on average, £25 a ton more than in 1955-6, the latter was a peak crop. Overall, plummeting coffee receipts led to a serious reduction in the commodity's contribution to the colony's export trade. ${ }^{6}$ During 1957-65, the value of coffee exports in relation to the total value of all agricultural exports fluctuated between a third and a half. Even so, the commodity maintained its position as Kenya's leading foreign exchange earner. The terms of trade throughout this period were generally unfavourable to Kenya, aggravating the impact of falling coffee prices.

The colonial government's commitment to European agriculture as the basis of Kenya's economy was thus tested, but this orientation had already been tempered from the 1930s by misgivings about undercapitalized and skill-deficient settlers taking up coffee planting. ${ }^{7}$ Whilst European estates and African smallholdings were mutually conditioning opposites of a 'dual economy', their relationship was also showing signs of potential conflict. The designated role of African smallholders was mostly to service the domestic market and provide a rural subsidy to African labourers on settler estates, but not to compete with the settler sector, oriented towards both domestic and overseas markets. In 1935, an emerging elite of African farmers was permitted to plant Arabica coffee, hitherto a privilege reserved to Europeans, as the Colonial Office pressed for an increase in African export production. However Africans were not

${ }^{4}$ Colin Leys, Underdevelopment in Kenya: The Political Economy of Neo-Colonialism, Berkeley and Los Angeles: University of California Press, 1975, p.41.

${ }_{5}$ The National Archives, Public Record Office (henceforth P.R.O.), C0/544/ Department of Agriculture Annual Report, 1958.

${ }^{6}$ Kenya National Archives (henceforth K.N.A.), Kenya Trade and Supplies Bulletin, November 1957.

${ }^{7}$ R. M. A.Van Zwanenberg, 'Kenya's primitive colonial capitalism: the economic weakness of Kenya's settlers up to 1940', Canadian Journal of African Studies, 9, 2, 1975,pp 280-3; C. C. Wrigley, 'Kenya: the patterns of economic life, 1902-1945', in V. Harlow, et al. [eds.], The History of East Africa, Vol. II, Oxford : Clarendon Press, 1965, pp.216-17. 
allowed to plant close to European farms in Central Province, on the pretext that this would act as a drag on prices for settlers, and that a lack of 'technical know-how' would spread crop diseases. This stipulation privileged African growers in the areas of Meru, Embu and Kisii, and it was in the most favourable conditions of Meru that smallholder production of Arabica coffee really took-off. ${ }^{8}$ Determined to take full advantage of the post-war boom in coffee, the colonial government further eased restrictions on African production after $1946 .{ }^{9}$ Initially, relatively few farmers were allowed to grow Arabica coffee, and the rate of expansion allowed for each grower was limited. By 1952, when the Emergency was declared, instigating the war on Mau Mau, African coffee production had increased to 11,864 licensed smallholders, farming an area of 3,038 acres. $^{10}$

African coffee production was further expanded as part of the government's counterinsurgency strategy, which sought to privilege 'loyalist' African farmers, in an attempt to isolate Mau Mau militants from the peasantry of central Kenya. Quite apart from the military necessities of the colonial war, the Colonial Office sought fiscal advantages from promoting African coffee farmers. ${ }^{11}$ There was already experience of their effectiveness in Tanganyika and Uganda, although the coffee produced in those territories was more often the less valued Robusta variety. ${ }^{12}$ The metropolitan treasury, guided by fiscal self-sufficiency, had long pushed to reduce the role of the subsidized settlers in Kenya's agricultural economy. Under conditions

\footnotetext{
8 Anne Thurston, Smallholder agriculture in colonial Kenya: the official mind and the Swynnerton Plan, Cambridge, 1987: African Studies Centre, pp. 5, 136; K. S. Watt, 'African Coffee', Journal of the Royal African Society, 36: 143, 1937, p. 194.

9 Judith Heyer, 'Agricultural Development Policy in Kenya from the Colonial Period to 1975,' in J. Heyer, P. Roberts, and G. Williams [eds.], Rural Development in Tropical Africa, London: Macmillan, 1981, p. 103. See also, Judith Heyer, 'The origins of regional inequalities in smallholder agriculture in Kenya, 1920-73,' East African Journal of Rural Development, 8 [1and 2], 1975; Martin Kilson, 'Land and politics in Kenya: an analysis of African politics in a plural society', Western Political Quarterly, 10, 1957; Gavin Kitching, Class and Economic Change in Kenya: The Making of an African Petite Bourgeoisie, New Haven : Yale University Press, 1980; Geoffrey Lamb, Peasant Politics: Conflict and Development in Murang'a, Lewes : Julian Friedmann, 1974; Hans Ruthenberg, African Agricultural Production Policy in Kenya 1952-1 965, Berlin : Springer, 1966; M.P.K.Sorrenson, Land Reform in the Kikuyu Country, Nairobi : O.U.P., 1967; R.M.A. Van Zwanenberg, 'The development of peasant commodity production in Kenya, 1920-40' Economic History Review, 27 [3], 1974; R.M.A.Van Zwanenberg, with Anne King, An Economic History of Kenya and Uganda, 1800-1970, London : Macmillan, 1975.

10 P.R.O./C0/544/Department of Agriculture Annual Report, 1952.

${ }_{11}$ Nicola Swainson, The Development of Corporate Capitalism in Kenya, 1918-77, London: Heinemann, 1980, pp.5-12.

${ }_{12}$ For Tanganyika, see Kenneth R. Curtis, 'Small is better: a Consensus of Peasants and Bureaucrats in Colonial Tanganyika' in William G.Clarence-Smith and Steven Topik [eds.], The Global Coffee Economy in Africa, Asia and Latin America, 1500-1989, Cambridge: Cambridge University Press, 2003, pp. 312-34. For Uganda, see C.C. Wrigley, Crops and wealth in Uganda, a short agrarian history, London: Oxford University Press, 1959.
} 
where many Kikuyu were, or had been, in detention, ${ }^{13}$ the colonial government seized the initiative to embark on a programme of rural restructuring and social engineering to produce an African yeomanry, though at the cost of forcing many European settlers out of production.

The Swynnerton Plan was advanced in $1954^{14}$, under the canopy of the Emergency. The plan combined the political intention of privileging loyalists with the economic goal of expanding the production of coffee and other primary commodities. Promoting a 'landed class' of commercially 'energetic' Africans and a 'landless' rural proletariat, the plan encouraged the consolidation of smallholdings, to be surveyed, registered and developed as freehold farms with titles. Initially only a small number of farmers were permitted to grow Arabica coffee, and the rate of expansion for each farmer was limited. Agricultural officers strictly enforced high standards of coffee husbandry, which led to the expanded production of low cost, high quality Arabica coffee. ${ }^{15}$ This put pressure on European growers to achieve the same outcome, but for many this was a goal which evaded them. The plan, passed off as a favour from liberalizing late colonialism, sought to evade African agitation for land in settler areas by breaking the cycle of land deterioration and rural poverty in the overpopulated reserves, moving the greatest possible numbers of Africans from subsistence to commercial farming. ${ }^{16}$ The government's ambitious policy was to 'double Kenya's coffee production.' ${ }^{17}$

The initial tempo of expansion was accelerated in response to unrelenting global market pressures from the mid-1950s, which compelled the colonial government to beckon broad layers of low cost African farmers into Arabica coffee production, in a bid to save its tax base. Local 'cess' payments, a levy on coffee farmers to support county council finances, and tax revenues from export sales, were essential to the government's budget. If the industry were allowed to shrink and shrivel, the effects would be felt throughout the entire superstructure of the colonial state, whose agricultural and veterinary departments mushroomed after 1945 during the course of the 'second colonial occupation'. During the war against Mau Mau, the coercive apparatus

\footnotetext{
${ }^{13}$ Caroline Elkins, Britain's Gulag: The Brutal End of Empire in Kenya, London : Jonathan Cape, 2005.

${ }^{14}$ R.J.M.Swynnerton, A Plan to Intensify the Development of African Agriculture in Kenya, Nairobi: Government Printer, 1954.

${ }^{15}$ Heyer, 'Agricultural Development Policy in Kenya from the Colonial Period to 1975', pp. 103-4.

${ }^{16}$ Thurston, Smallholder agriculture, p.77.

${ }^{17}$ East African Standard (henceforth E. A. S.) 25th October 1958: 'Odd policy on coffee - assistance likely to be needed in marketing'.
} 
and provincial administration was also greatly expanded. ${ }^{18}$ To meet the rising costs of this enlargement, African coffee production grew more rapidly than anticipated in the Swynnerton Plan. By 1960, 33,000 acres of African-grown coffee had been planted by 105,000 growers, averaging less than one-third of an acre each. The Swynnerton target for 1968 was passed in 1962-63, and almost doubled by 1964, when nearly 236,000 growers had planted 125,000 acres. Spurred on by the lifting of restrictions on African coffee production, the crop rapidly expanded, with more than 110,000 African growers producing alongside 1,200 European farms and plantations in $1960 .{ }^{19}$ The increased output of a variety of crops from small farms, associated with the Swynnerton Plan, involved the injection of substantial resources in the form of infrastructure, processing and marketing facilities, and showed an annual rate of growth of marketed output of $7.3 \%$ from 1954 to 1963 , and $12.6 \%$ from 1964 to $1970 .{ }^{20}$ By 1967 the proportion of marketed output that came from small farm areas had reached $50 \%$, with coffee production responsible for around half of this output.

The powerful emergence of small African farmers was controlled by centralized institutional structures, which became dominant features of the industry. The Coffee Board of Kenya (C.B.K.), founded in 1933, was responsible for regulating production and the organization of coffee auctions. The Coffee Marketing Board (C.M.B.), set up in 1945, held a similar grip over coffee sales and managing payments through a pool system. In addition, the Kenya Planters Cooperative Union (K.P.C.U.) was a country wide co-operative, which was owned and managed entirely by coffee growers through a board of directors. It was founded in 1937 as the Thika Planters Co-operative Union, to purchase supplies for its members. In 1945, the colonial government enacted a new co-operative ordinance, which enabled the K.P.C.U. to acquire the entire agency business for the co-operative society sector of the coffee industry. Its membership comprised all coffee co-operatives and over $90 \%$ of coffee estates. In 1947, the K.P.C.U. completed its milling monopoly by purchasing the mills of the East African Coffee Curing Company, an amalgamation of several small mills, which incorporated coffee milling, liquoring and storage. The main role of the K.P.C.U. was to mill and grade parchment coffee

\footnotetext{
${ }^{18}$ Carl G.Rosberg and John Nottingham, The Myth of Mau Mau: Nationalism in Kenya, New York and Washington: Praeger, 1966, p.293.

19 David Hyde, 'Plantation struggles in Kenya: trade unionism on the land 1945-65,' Ph.D [S.O.A.S., 2001]: Appendix 36 'Acreages, Yields and Remuneration of African and European Coffee Production, 1946-65', p.304.

${ }^{20}$ Heyer, 'Agricultural Development Policy in Kenya from the Colonial Period to 1975', p. 106.
} 
from estates and societies. It also provided advice on coffee husbandry, agricultural inputs such as fertilizers and machinery, short-term credit, transit and warehousing, receiving and channeling payment to members together with education and information to coffee growers. The K.P.C.U. paid farmers through a pool system, whereby sale proceeds were combined before determining the final average rate to pay farmers. Payments were made after deducting marketing expenses incurred by the C.B.K., and the final price was the same for all farmers. ${ }^{21}$

Exports from European-owned plantations declined in relation to rising volumes of African production. ${ }^{22}$ The state was obliged to sacrifice uncompetitive small and medium European producers at the altar of the industry's survival, uprooting its erstwhile biases, and abandoning many of the previous favours granted to settlers. That said, some large plantation companies also made gains at the expense of small to medium planters, whose profit margins were close to collapse. The government's general economic predicament disabled any commitment to underwrite the losses incurred by falling prices through subsidies to the industry. Indeed, it was rather looking at ways to raise extra revenue to ease its financial burden. As economic pressures mounted, only limited financing for estate and plantation production remained available from the Board of Agriculture, through its rehabilitation and development funds, the European Agricultural Settlement Board, and the Land and Agricultural Bank. ${ }^{23}$ The Board of Agriculture warned settler farmers that they could not be shielded 'against the effects occasioned by the present shortage both of revenue to finance current needs and of loan funds for development.' ${ }^{24}$ To be sure, there was a rapid expansion of banking and financial institutions in the colony during this period, but commercial banks provided a decreasing amount of agriculture's capital requirements. By 1955, commercial banks were pursuing a policy of disengagement from long-term loans to European farmers, as the

\footnotetext{
${ }^{21}$ E.A.S. $28^{\text {th }}$ July, 1961, 'The Coffee Industry - a background'; see also K.P.C.U. [1977], I.C.O. Library [no reference].

${ }^{22}$ Hyde, 'Plantation Struggles in Kenya', Appendix 36, p.304; A. Low and Alison Smith, eds., History of East Africa, Vol. III, Oxford, 1976, Table 10, p. 591. See also : Nicola Swainson, The Development of Corporate Capitalism, London : Heinemann, 1980; Gary Wasserman, The Politics of Decolonization: Kenya Europeans and the Land Issue, Cambridge : Cambridge University Press, 1976.

${ }^{23}$ Michael McWilliam, 'Banking in Kenya, 1959-60', East African Economics Review, 9, 1, 1962, pp. 18, 24.

${ }^{24}$ K.N.A./Department of Agriculture Annual Report, 1957.
} 
lion's share of increased local lending flowed into short-term commercial credit to finance imports, which had been in short supply. ${ }^{25}$

The state reduced financial assistance to settlers when they needed it most. As global coffee prices plummeted, European farmers found it increasingly difficult to compete with low cost African cultivators, exposing long-term structural problems in Kenya's economy. The government endeavoured to show some support, by providing extension staff to supervise processing factory work and to teach growers, and by helping emerging co-operatives. However, officials insisted that this was to be paid for from the industry's profits, through extra cess payments, set at $5 \%$ of the value of clean coffee, and a $12.5 \%$ export tax. The latter measure provoked settlers to found the Kenya Coffee Growers Association [K.C.G.A.], and the tax was revoked in 1957. ${ }^{26}$ The K.C.G.A. was more generally created to meet competition from abroad, regulate conflicts of interest, and centralize industrial relations for disputes mediation with workers.

It was legislation to end income tax relief that provoked the greatest furore, as coffee planters had earlier been permitted to average their incomes over a number of years. ${ }^{27}$ Forty Kiambu coffee growers assembled to express 'strong opposition' to Finance Minister Vasey's measure, and they demanded that the C.B.K. represent their concerns. They pleaded that the 'iniquitous proposal' would make it difficult for them to 'make ends meet', and drew up their own proposal for a tax rate which 'should not exceed' 12 shillings in the pound, with exemptions for development expenditure. ${ }^{28}$ Their resolution, which was forwarded to the Nairobi coffee conference in July 1958, vocalized the grievances of European planters everywhere by calling for an independent inquiry into the budget proposals 'with a view to ending the need for such high taxation.' ${ }^{29}$ To placate the outcry the C.B.K. acknowledged that 'planters were perturbed at the rate of the $\operatorname{tax}^{30}$ and set up a committee to look into the

\footnotetext{
${ }^{25}$ McWilliam, 'Banking in Kenya', pp.18, 24, 33; Van Zwanenberg, An Economic History, p.294. See also Michael McWilliam, 'The managed economy: agricultural change, development and finance in Kenya, 1945-1963' in D.A. Low \& Alison Smith, eds., History of East Africa, Vol. III, Oxford : Clarendon, 1976.

${ }_{26}$ E.A.S., 28th March 1958: 'Coffee profit tax system ends'.

27 ibid.

${ }^{28}$ E.A.S. 9th June 1958: 'Coffee Board committee to study new tax'.

${ }^{29}$ E.A.S. 24th June 1958: 'Kiambu planters tax resolution - discussion at conference'.

${ }^{30}$ E.A.S. 9th June 1958: 'Coffee Board committee to study new tax'.
} 
controversial deduction. Nonetheless, the government proceeded with its budget proposal for an undistributed income tax at the rate of 15 shillings in the Kenya pound. Even the C.B.K. protested that the Income Tax [Management] Bill would prevent smaller planters from accumulating the financial reserves necessary to shield themselves against the almost certain prospect of 'a serious drop in prices during the next few years.' ${ }^{31}$

The financial and infrastructural demands of the Emergency compounded these problems, at a time when returns from coffee were variable and unpredictable. The East African Railways and Harbours (E.A.R.H.) used to provide cheap transportation, underwriting the profitability of Kenya's settler economy, but it was no longer able to sustain this function. Perennially low freight charges were no longer affordable, as major investment was required by the mid-1950s, at a time when the Renewals Fund was depleted. The E.A.R.H. needed to meet the requirements of severe capital depreciation brought on by the post-war export drive, as well as the demands of the colonial war against Mau Mau. Its increased charges were a further cost that many coffee growers were unable to contend with. ${ }^{32}$ Deductions to pay for the security forces, believed to amount to one bag of coffee in eight, were a further bone of contention.

\section{Quantity into quality: Kenya's stresses of global competition}

As the global coffee crisis unfurled from the mid-fifties, sustaining and increasing the high quality of Kenya's Arabica beans became of paramount importance. ${ }^{33}$ Kenya's Arabica coffee had already established a market reputation as the best of its kind, and since 1945 it had been fetching higher prices than Columbia, its closest competitor. It had been a mainstay of the specialty coffee market in Europe and the U.S.A., and was a key component for roasters seeking to add acidity and sweetness to their blends. West Germany was Kenya's best customer, paying premium prices at auction, where class 1 coffee fetched up to $£ 574$ a ton in good years. However, just 8,800 tons of Kenya's 1957 coffee crop of 22,284 tons were sold at the class 1

\footnotetext{
${ }^{31}$ E.A.S. 31st October 1958: Coffee industry protests - proposed tax rate penal to smaller companies'.

${ }^{2}$ David Hyde, ‘East African Railways and Harbours, 1945-60: A Crisis of Accumulation' (forthcoming).

${ }^{33}$ Mario Samper, 'The Historical Construction of Quality and Competitiveness: A Preliminary Discussion of Coffee Commodity Chains', in William G. Clarence-Smith and Steven Topik, eds., The Global Coffee Economy in Africa, Asia and Latin America, 1500-1989, Cambridge: Cambridge University Press, 2003, pp. 120-53.
} 
average of $£ 453$ a ton during the $1956-7$ season. Overall the season's average across all grades was just $£ 388$ a ton, $£ 84$ down on the previous year's figure. When Hamburg buyers gave notice that only if 'quality standards' were maintained would Kenya's coffee 'be assured of a good market reception', their concerns were underlined by the C.B.K.'s Chief Liquorer who conceded that its quality was now 'far below that on which its name had been built.' ${ }^{34}$ Kenya's market in West Germany was dependent on a few large buyers, and the failure of a single one of these to purchase presaged disaster. With the colony's reputation as a producer of the world's finest liquoring coffee in question, there was pressure to increase production and sustain quality, despite falling prices and growing stocks.

Globally, the fiscal year 1956-7 ended with a surplus of 522,000 tons of unsold coffee, two thirds belonging to Brazil. ${ }^{35}$ These unsold surpluses were carried over into the following year to be set against rising production, thus taking the crisis to a new stage, and depressing prices still further. In an attempt to stabilize prices, Latin American producers signed the Mexico Agreement in 1957, renewed a year later as the Latin American Agreement ${ }^{36}$, which introduced stringent inter-American export quotas. However, the continued expansion of African coffee cultivation threatened the success of a pact that covered only Latin America. African growers competed with Latin American producers in all markets, including those in North America. African growers were thus enticed to participate in a short-term international agreement in 1959, renewed in 1960, and extended in 1961 to include twenty-eight signatory territories, representing about $90 \%$ of world coffee exports. ${ }^{37}$ The proceedings of the annual Nairobi coffee conference, held in July 1957, were dominated by this global crisis. Delegates from the C.B.K.

\footnotetext{
${ }^{34}$ E.A.S. 29th November 1957: 'Sharp drop in the quality of Kenya coffee'.

${ }^{35}$ All references to coffee weights throughout the text are in long tons. 1 bag of coffee weighed, on average, 0.058 ton.

${ }^{36}$ Daviron and Ponte, The Coffee Paradox, p.86

${ }^{37}$ Richard B. Bilder, 'The International Coffee Agreement, 1962', The American Journal of International Law, 57, 4, 1963, pp. 888-92. See also Andreas F. Lowenfeld, 'International Commodity Controls - Some Lessons from the Coffee Agreement', The American Journal of International Law, 61, 3, 1967, pp. 785-9; Ernest Rubin, 'Questions and Answers on Coffee Statistics', The American Statistician, 22, 3, 1968, pp. 42-3; Irving B. Kravis, 'International Commodity Agreements to Promote Aid and Efficiency: The Case of Coffee', The Canadian Journal of Economics, 1, 2, 1968, pp. 295-317; Kenneth D. Frederick, 'Production Controls under the International Coffee Agreements: An Evaluation of Brazil's Programs', Journal of Interamerican Studies and World Affairs, 12, 2, 1970, pp. 255-70; Richard B. Bilder, 'The International Coffee Agreement: A Case History in Negotiation', Law and Contemporary Problems, 28: 2, 1963, pp.328-91.
} 
and the C.M.B. expressed anxieties over falling sales. Plans to re-establish Kenya's pre-eminent position in the British market, now accounting for a mere $6 \%$ of exports, were discussed. ${ }^{38}$

Further unease emerged over threats to Kenyan producers emanating from protectionist measures adopted by the newly formed European Economic Community. This took the form of a $16 \%$ levy on coffees originating from overseas territories unattached to the six member states. $^{39}$ This was a major setback, since a large portion of East African coffee had established itself on European markets after 1945. There were particular fears for Kenya's higher grade coffees, which continued to be dependent on West German importers as their principal buyers, whereas Britain and the U.S.A. were the main customers for ordinary grades. With the prospect of East African coffee exports being locked out of Europe, feverish attempts were made to find alternative markets, notably in North America. The United States were cultivating allies in Africa, coveting access to Britain's protected colonial markets. ${ }^{40}$ The battle for quotas gave a huge political advantage to the Americans, as it was by far the largest single market, consuming more than half the world's coffee. America's intake of East African coffee, though still very small in proportion to coffee imports from Latin America, had increased by 150\% since 1953. The President of the National Coffee Association of America, on a visit to Nairobi, assured planters of more sales, provided that 'the price remained right and the quality was maintained. The demand for your coffee is growing in our country and production is rising in Africa, so if your reputation for good coffee remains as high as it has done for some time, we will take more of it.' Asked if importing East African coffee would affect any coffee agreement with Latin American growers he replied, 'We have no agreements with any body. America believes in free trade, if you have coffee that we like we will take it.' ${ }^{41}$

Michael Blundell, Minister of Agriculture, grappled with these dilemmas. In an address to the annual conference of the Kenya National Farmers Union [K.N.F.U.], held in Nairobi in May 1958, he acknowledged that the 'most damaging blow to the economy as a whole has been

\footnotetext{
38 E.A.S. July 12th,1957: 'Move to widen coffee talks - African representation'; E.A.S. July 27th, 1957: 'Advice on coffee - Kenya's need for wider exchange of views'.

${ }^{39}$ E.A.S. $6^{\text {th }}$,May 1958 : 'Common Market threat to East African coffee'.

${ }^{40}$ K.N.A./'East Africa - a Market for U.S. Products in Kenya, Tanzania and Uganda', a supplement issued by the U.S. Department of Commerce/ Bureau of International Commerce.

${ }^{41}$ E.A.S. 6th April, 1957: 'US may import more coffee from East Africa'.
} 
the steep fall in coffee prices' ${ }^{42}$ The world market had been temporarily stabilized only by the large stocks retained by dominant producers, albeit at the expense of building up even larger excesses, which Blundell estimated would exceed 1,566,000 tons beyond the estimated world annual consumption of some 2,204,000 tons. This was underlined by a report issued by the United Nations Food and Agricultural Organization, which estimated that world coffee production for 1958-9 would be $9 \%$ higher than the previous year. Blundell drew attention to the support the government derived from the coffee industry, and emphasized that 'it was reluctant to enter a quota system to reduce production, ${ }^{43}$ a strategy advocated by the American government's Coffee Study Group, based in Washington. ${ }^{44}$

Blundell's stance was founded on the assumption that rising coffee production amongst low cost African farmers would help the industry to meet 'the challenge of falling prices...' ${ }^{45}$ In full knowledge of the global dimensions of overproduction, Blundell's proposal to step up production followed logically from the experience of the 1930s depression years, when African farmers in other colonies were urged to produce their way out of the crisis. It was assumed that African smallholders and their families would work longer hours, labour more intensively, and be prepared to wait for payment in the knowledge that the crop was their own. This strategy was facilitated by lifting erstwhile restrictions on African coffee production, and was sustained by support from the state through the expansion of extension services. It was believed that this would also pressure settlers into reducing their overheads, and most were compelled to forego the increased costs of spraying, fertilisers and mechanization. At the same time, Blundell repeatedly pointed to the inevitability of 'severe competition' in world markets, and warned that the region's coffee producers would 'continue to attract good prices only if we maintain quality.' Overall, Blundell understood that the industry would have to undergo a profound restructuring if it was to survive, and that many European coffee farmers would necessarily go to wall, a price which he was privately and reluctantly resigned to paying. The aim was to maximize coffee exports at the minimum possible production cost, whilst preserving traditional

\footnotetext{
${ }^{42}$ E.A.S. 2nd June 1959: 'Drop in coffee prices continues'. More generally, see Michael Blundell, So Rough a Wind, London, 1964.

${ }^{43}$ E.A.S. 2nd June 1959: 'Demand not keeping pace with production rises.'

${ }^{44}$ International Coffee Study Group, International Organization, 14:2, 1960, pp.367-368, and 14:4, 1960, p. 695.

${ }^{45}$ E.A.S. 13th November 1958: 'Minister reviews colony's farming prospects - warning of severe coffee price drop'.
} 
markets for premium Arabica beans. The urgency of this strategy was determined by the haste to curtail fiscal losses and maintain hard currency earnings. ${ }^{46}$

There was a risk that intensified labour processes would lower quality, thus compromising sales. Alongside an increased incidence of leaf rust and coffee berry disease, coffee growers had suffered several seasons of bad weather, and there was a marked tendency to allow trees to overbear. ${ }^{47}$ Many casual field workers picked unripe green cherry to fill their four-gallon paraffin tins, in response to low picking rates and rationalized working practices on coffee plantations. ${ }^{48}$ This was compounded by the extended employment of female and child labour, to fill the huge gaps in the workforce left by detention and by restrictions placed on the employment of Kikuyu males, many of whom were experienced plantation workers. European coffee planters lobbied for the lifting of Emergency restrictions on the employment of former detainees, and generally attempted to sustain quality by opting for low-wage and labour intensive methods. However, this provoked an avalanche of plantation strikes, fuelled by the unrestricted entry of thousands of erstwhile Mau Mau detainees onto the labour market in Kenya's plantation districts in Central Province. ${ }^{49}$

In addressing these issues, the C.B.K. and the C.M.B. did not see eye to eye. The C.B.K. made a virtue of falling prices, and advanced an activist strategy of 'demand management,' a controlled release of surplus stocks in conjunction with expanding sales. Whilst this was calculated to ease the pressure on producers, it put wide layers of settlers in jeopardy by compelling them to sell their coffee at below its costs of production. The C.M.B.'s more passive approach was to wait for an expected cycle of higher coffee prices, which would 'come quickly enough.' Until the arrival of this scenario, East Africa 'could get through.' If surplus stocks were released, the prices of all coffees would tumble 'very steeply.' The board thus advocated a cautious policy of bringing supply and demand into equilibrium through stimulating demand, but in tandem with restrictions on production and new plantings. ${ }^{50}$ This approach was

\footnotetext{
46 E.A.S. 28th May 1958: 'Kenya farms faced with worst crisis since 1930s - cuts in costs essential'.

47 ibid.

${ }^{48}$ Hyde, 'Plantation struggles in Kenya', p.77.

49 ibid., Appendix 33: Anatomy of the Coffee Industry in Thika district giving details of ownership and acreages of estates, tribal and gender composition of the workforce as at August 1'st, 1960, pp.287-8.

${ }^{50}$ E.A.S. 21st November 1958: 'Cheaper prices good for coffee in the Long run - report on world trade talks'.
} 
overtaken by events, as prices of lower to medium grades of Kenyan coffee slid sharply in December 1958, ending down by $£ 20$ to $£ 30$ a ton, with losses estimated at 'about $£ 1,000,000$ '. ${ }^{51}$ The East African Coffee Roasting Association insisted that nothing less would do than to drop prices, ${ }^{52}$ while Brooke Bond reduced their prices by 80 cents a pound without warning, in a bid to outdo their competitors.

With the approach of the 1959-60 season, the Latin American producers, led by Brazil and Columbia, responded to the worsening crisis with draft proposals that Britain's African colonies (Kenya, Uganda, Tanganyika and Sierra Leone) should limit their exports to 113,042 tons, $^{53}$ thereby challenging the strategy of dropping prices whilst expanding sales. The chairman of the C.M.B., R. S.Wollen, was 'categorical' in his announcement to the annual Nairobi coffee conference that Kenya 'would not be a signatory to this scheme.' He argued for the scarcity value of Kenya's high quality coffees, and maintained that it was cheaper coffees that were in 'oversupply.' Wollen remained 'confident that however much coffee is released in the world we shall always be able to sell our total production and at some premium for quality.' Vocalizing the position of a significant lobby that favoured going it alone, Wollen urged that Kenya's producers should not be swayed by the threat of catastrophe, since the quality of their coffees was above the rest. Kenya's coffee production was increasing by 2,500 tons a year, and plans were underway to develop the potential market amongst Africans in Kenya for cheap coffee, whilst market outlets in Rhodesia and South Africa were also being explored. In reality, these options were barely enough to make a difference, and Kenya's premium coffees were tethered only by a slender thread to German buyers. In a more sober frame of mind, Wollen was 'frankly terrified' that if Brazil were to release her surpluses onto the world market 'the fall in the price of all coffees would be catastrophic. ${ }^{54}$

Talks began in Washington in June 1959 for a global marketing pact for 1959-60, with suggestions of an increased export quota of 2,335,776 tons matched against an estimated annual world consumption of 2,204,000 tons. ${ }^{55}$ In addition to existing stocks, such a continued excess of

\footnotetext{
${ }^{51}$ E.A.S. 2nd December 1958: 'Concern at slide of coffee prices - effect on Kenya economy'.

52 ibid.

${ }^{53}$ E.A.S. 7th July 1959: 'Alarm at coffee proposal - threat to output from East Africa.'

${ }^{54}$ E.A.S. 25th June 1959: 'Kenya opposes plan to limit coffee exports - assured market for quality goods'.

55 E.A.S. 24th June 1959: 'Talks in U.S. on Coffee Agreement'.
} 
supply would almost certainly keep prices in the doldrums. There were signs of brinkmanship among the warring factions, who taunted each other with the prospect of market collapse, in order to extract a higher quota for themselves. Kenya's C.M.B. held fast to its belief that African producers had a significant leverage over their Latin American rivals, and that Brazil would not seek 'to prompt such a disaster.' However, Brazil and Columbia sought to entice the Africans into a world-wide quota agreement, which they would dominate. The suspicion amongst East African producers was that the provisions of the proposed agreement did 'not augur entirely well' for them, and they barely disguised their deep resentment at a pact that would involve the region's producers retaining some 24,000 tons of their produce 'just to protect the artificially high prices' sought by Latin American producers. ${ }^{56}$ However, the leading settler politician, Bruce Mackenzie, cautioned against complacency, and warned that the prospect of Brazil offloading its stockpiles, accumulating at 58,000 tons a year, was a real one. ${ }^{57}$

Finally, an agreement on export quotas was reached, following a surprisingly abject capitulation by East African producers who agreed to withhold 54,000 tons from the market, more than double the previous figure. This submission coincided with a new provision in the pact, excluding any new markets developed by producing countries from export quotas ${ }^{58}$, though it was far from certain that non-quota markets would suffice to soak up surpluses. This problem was highlighted by figures released by the American Department of Agriculture, forecasting record production levels of African coffee, estimated at 614,800 tons for 1959-60, of which 585,800 tons would be exportable, 5\% above the previous year. ${ }^{59}$ The situation worsened in the following year, as East African producers signed another short-term international coffee pact, forfeiting the right to restrict their exports voluntarily. They were now bound by export quotas, which were revised downward by 11,600 tons to 138,040 tons for 1960-1, given that prices had been falling 'throughout the season for all grades and classes', a trend compounded by the generally poor quality of the season's crop. ${ }^{60}$

\footnotetext{
56 E.A.S. 26th August 1959: 'Coffee export control'.

${ }^{57}$ E.A.S. 2nd September 1959: 'Stockpiling of coffee threat to world price'.

58 E.A.S. 26th September 1959: 'Agreement signed on coffee quotas'.

${ }^{59}$ E.A.S. 30th September 1959: 'Record coffee crop in Africa Likely - U.S. Report'.

${ }^{60}$ E.A.S. 10th December 1960: 'Coffee group to stabilise prices all over Africa'.
} 
Quotas aside, Blundell laid down the government's policy that Kenya could 'not contemplate any direct control of production, whatever long term world agreement was concluded in future.' ${ }^{61}$ In promoting Arabica coffee as 'an excellent cash crop for the African smallholder', ${ }^{62}$ Blundell took the opportunity to stress again the government's concern to encourage African farmers who were in a stronger position to keep their production costs low. This would enable the C.M.B. to auction larger quantities of coffee for non-quota markets, with less fear of the commodity being sold off at below its costs of production and distribution. This indicated the government's intention to open the gates even wider to broader layers of African farmers engaged in coffee production. Blundell qualified his support for quotas if the reduction 'was not too great', so that producers were prepared for the 'upward swing in the coffee cycle.' ${ }^{63}$ Blundell's formula was that quotas were compatible with the expansion of coffee production, as long as African farmers were empowered to sustain the industry until prices were able to climb out of their trough. As only the fittest European producers would survive these trials and tribulations, Blundell envisioned an industry in which there was room for both low cost African farmers and rationalized European producers.

Blundell also hoped that Kenyan growers could survive 'a complete price collapse of Brazilian arabicas,' as they 'could probably continue to command premium prices,' on the strength of reputed excellence. Nonetheless, he was attentive to the risk of a price war, in which 'there was a danger that the price of even the best qualities would decline precipitously.' 64 During 1961, the continued fall in world prices had a further dramatic impact on Kenya's economy. Alarm bells rang at the Nairobi coffee auctions, where class 6 coffee sold at an average of 311 shillings per hundredweight, as compared to 366/- in the previous season. ${ }^{65}$ The Department of Trade and Supplies revealed that the overall value of Kenya's exports had shrunk by $7.4 \%$ during 1960 , mostly due to lower coffee prices, at a time when coffee accounted for $37.8 \%$ of Kenya's total exports. ${ }^{66}$

\footnotetext{
61 ibid.

62 ibid.

${ }^{63}$ E.A.S. 7th May 1961: 'Minister on coffee treaty - Kenya would not accept output limit'.

64 ibid.

65 E.A.S. 10th May 1961: 'Coffee auction'.

${ }^{66}$ K.N.A./ Kenya Trade and Supplies Bulletin, June 1961.
} 
A recurrent emphasis on quality and productivity surfaced at the annual Nairobi coffee conference in July 1961, attended by 55 representatives of coffee organizations and societies from the colony. Roger Swynnerton, Permanent Secretary at the Ministry of Agriculture, echoed the constant refrain of coffee industry spokesman with a sermon on 'sound development and quality maintenance,' which were crucial to the 'survival of the coffee industry at a critical time'. Swynnerton advocated an 'increase in advisory and research services,' whilst keeping 'a close eye' on foreign competitors. He reminded delegates that while the price of coffee had fallen by $£ 200$ a ton during the previous four years, the industry had managed to sustain itself by exporting, on average, more than $£ 10,000,000$ worth of coffee annually, through increasing production by more than 9,000 tons a year and by 'preserving quality.' ${ }^{67}$ Nonetheless, without a larger quota to soak up cumulative surpluses, and given the limited absorption capacity of nonquota markets, such a strategy was storing up inescapable problems for the future.

Agricultural research underpinned higher production volumes. To keep the industry safe from the onslaught of coffee berry disease, leaf rust and insect pests, a research grant of $£ 21,235$ had been announced in May 1960 from the Colonial Development and Welfare Fund. Research into methods of increasing crop yields and soil conservation were also prioritized. ${ }^{68}$ The most important work occurred at the Coffee Research Station situated on Jacaranda Estate in Ruiru. Working closely with the Soil Conservation Service, the station's research focused on entomology, plant physiology and pathology and agricultural chemistry. There were field trials for appropriate fertilizers and methods of mulching, pruning, cultivation, spraying and irrigation. Varieties underwent trials at the station's coffee nurseries. These efforts were supported by a major reconstruction programme at the Kenya Planters' Co-operative Union mill in Nairobi, with plans to process 200 tons daily.

\section{A worsening crisis}

The crisis entered a new phase in September 1961, marked by a sudden deepening of the depression in world prices. At the 'first of the season' coffee auctions in Nairobi, class 6 coffee fell dramatically to just 292 shillings a hundredweight, with prices of most grades 'generally

\footnotetext{
${ }^{67}$ E.A.S. 29th July 1961: 'Quality the key to coffee Industry survival - need for more research and advice stressed'.

${ }^{68}$ E.A.S. 13th May 1960: ‘ $£ 21,235$ aid for coffee research'.
} 
down' on the previous season's close. The 'downward drift' 69 in world prices was so serious that the international pact for 1961-2 appeared to be on the brink of failure, amidst bitter internal squabbles, with some producers on the verge of breaking ranks. As the fiction of controlled markets began to crumble, political upheavals in Brazil created unease that proponents of releasing that country's surpluses would gain the upper hand. This seems to have intimidated the East African producers into accepting a 3\% cut in export quotas, from 85,175 tons in 1960-1 to 82,620 tons in 1961-2. This curb on exports could only worsen the region's economic position in the short-term. The international coffee pact, renewed 1961-2, seemed unable to arrest the slide in world prices, with the Financial Times anticipating that the 'likelihood is that prices will continue to fall for some time to come.' ${ }^{\prime 0}$ To address these problems, the C.M.B. resorted to auctioning even more coffee in non-quota markets. ${ }^{71}$

Prospective price collapse and internecine war amongst coffee producers generated much unease in Britain and Kenya. The future of Kenya's involvement in international coffee agreements had been the subject of talks in London in June 1961 between representatives of the three East African territories and the British government. Britain's intervention at this juncture was almost certainly related to its concern for the economic and political stability of Kenya during decolonization. ${ }^{72}$ R.S.Wollen told Nairobi Rotarians that no country on the verge of independence would weather the economic trouble which would follow a drop in coffee prices.' At present rates of growth, Kenya was likely to double its annual production of 29,000 tons within five years. Wollen warned that without an international agreement, coffee producing countries would face a price war, and, 'should this happen,' Kenya would be lucky to sell its crop at a quarter of the present price. Whilst Wollen welcomed the efforts of the colonial government towards negotiating an agreement, he cautioned that 'it will involve sacrifices and may be unpopular.' He drew further attention to Brazil's enormous stockpile of 2,320,000 tons

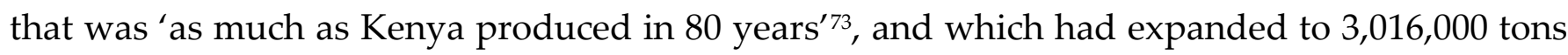
by the close of $1962 .{ }^{74}$ Brazil stood accused of using this coffee mountain to browbeat smaller producers to fall into line behind its dominance of renewable and short-term global coffee

${ }^{69}$ E.A.S. 21st September 1961: 'Peril in falling coffee prices - treaty's aim being ignored -chairman'.

${ }^{70}$ Cited in E.A.S. 14th March 1962: 'More coffee price fall likely: talks in U.S. vital to East Africa'.

71 ibid.

${ }^{72}$ E.A.S. 21st June 1961: 'London coffee talks clarified issues - policy study made'.

${ }^{73}$ E.A.S. 13th April 1962: 'Drop in prices would ruin Kenya warns chairman of coffee board'.

${ }^{74}$ K.N.A./AMC 7/20: Verjee Report, November 1962. 
agreements. This knife at the throat of Kenya's coffee planters impelled sharp changes in social relations within the country, as it moved closer to independence in $1963 .{ }^{75}$

At the 1962 International Coffee Conference, global export levels for 1962-3 were fixed at 2,610,000 tons adding another 464,000 tons to unsold stocks. Whilst 'stabilizing' markets and holding off a price war, this aggravated the crisis of overproduction. Whereas under previous agreements the East African territories had shared a single quota, Kenya now had its own quota of 30,000 tons as part of a five-year arrangement, whereby the government settled to retain $12 \%$ of its total crop. However, its crop estimate of 38,000 tons for the 1962-3 season was 11,000 tons in excess of the previous season, from which there was an unsold surplus of 3,000 tons, with substantial future increases predicted by the C.B.K. The board expressed concern that Kenya was on course to exceed its export quota to the traditional high priced markets by more than $20 \%$, and that efforts to unload this surplus onto non-quota markets would cost the planter 'quite a lot of money.' ${ }^{76}$ Some 10,000 tons were to be disposed of locally and onto non-quota markets, notably in Eastern Europe and East Asia, though at a 'substantial reduction' on the quota price. With Kenya's coffee production 'increasing far more rapidly than its export outlets' there was 'drastic control' over new plantings in an effort to come into line with export quotas. ${ }^{77}$ This compounded the problems created by the industry's tightest ever margins. In the previous four seasons the average price on local markets had been approximately £52 a ton, one-sixth of the price obtained on quota markets, and the average price obtained on non-quota markets approximated $£ 150$ per ton, giving a combined non-quota average of $£ 132.5$ per ton. ${ }^{78}$ Such a low price acted as a drag on the much higher average price attained by coffee sold on quota markets. ${ }^{79}$

Unless the world price for Kenya's high quality premium Arabica showed a steep rise, or it was able to substantially increase the volume and price of its sales, the Verjee Tribunal, believed that the industry would 'be placed in a dangerously precarious position.' This body was convened in 1962 to investigate the avalanche of coffee plantation strikes which erupted in response to intensified labour processes brought on by declining world prices. The implications

\footnotetext{
75 Hyde, 'Plantation struggles in Kenya.'

76 E.A.S. 1st December 1962: 'Kenya coffee still the world's best'.

77 E.A.S. 22nd November 1962: '5,000 ton target for non-quota markets: Kenya plans to raise exports of coffee'.

${ }^{78}$ K.N.A./AMC 7/20: Verjee Report, November 1962.

${ }^{79}$ E.A.S. 6th February 1963: 'Coffee Auctions.'
} 
for the rate of profit were illustrated by figures [see table], presented to the tribunal by the general manager of Socfinaf, Kenya's largest coffee plantation company, which owned some 12 estates spread over 37,960 acres. To avoid suffocation under a mountain of cumulative surpluses, the Verjee Tribunal urged that 'no effort should be spared' to promote sales in nonquota markets. ${ }^{80}$ Nonetheless, this could only be a short-run solution, since all world producers were competing in non-quota markets. Ultimately, this crisis necessitated the destruction of vast quantities of surplus coffee, to create an equilibrium between buyers and sellers.

Table 1: Coffee sales to quota, non-quota, and local markets, $1962 .{ }^{81}$

\begin{tabular}{|l|l|l|}
\hline Sales & Tonnage & Average price per ton \\
\hline Quota markets & 30,000 & $£ 300$ \\
\hline Local & 1,200 & $£ 52.5$ \\
\hline Non-quota markets & 9,800 & $£ 150$ \\
\hline Total & 41,000 & \\
\hline Overall average price per ton & & $£ 257$ \\
\hline
\end{tabular}

During 1961, Kenya's premium grade coffees rose by $£ 28$ to an average price of $£ 348$ a ton, but it British market contracted and recently gained markets in Holland and Sweden were lost. ${ }^{82}$ The survival of the industry now hung largely by the slender thread of the market in West Germany, Kenya's 'most important buyer,' which was menaced by E.E.C. regulations. ${ }^{83}$ Renewed concerns over quality surfaced with signs that German roasters 'were turning away' from Kenya coffees. German buyers were unwilling to pay high prices for coffee of declining quality, and were looking at other suppliers. In November 1962, Schweggmann and Co., agents for East African coffees in Bremen, confirmed that 'most' German coffee roasters were 'not using' Kenya coffee in their blends anymore, because of the drop in quality. They complained that 'the well known attributes of fine liquoring Kenya coffees - flavour and acidity - are rarely seen today.' At this point Kenya was exporting half its crop to Germany, though 'only a few

\footnotetext{
${ }^{80}$ K.N.A./AMC 7/20: Verjee Report, November 1962.

${ }^{81}$ K.N.A./AMC 7/20: Verjee Report, November 1962.

82 E.A.S. 28th July 1962: 'New markets lost by increased prices for coffee'.

${ }^{83}$ E.A.S. 1st August 1963: 'Coffee delays worry trade'.
} 
buyers are involved and should they change their mind the export situation could change in a few days. ${ }^{\prime} 4$

\section{The International Coffee Agreement and the rebirth of protectionism}

World producers were now on a collision course, which the U.S. moved to arrest through initiating longer-term quota agreements. The price falls consequent on the end of the Korean war, together with cuts in American foreign direct investment in Latin America, had led rival producers to seek to make up for lost revenue. Denied the expected resources for diversification, which had been channeled into Western Europe's post-war recovery, Latin American producers were forced back into an accentuated dependency upon raw materials. ${ }^{85}$ East African producers, starved of investment and compelled to accelerate production to generate the hard currency to meet the demands of Britain's post-war reconstruction, were also forced to tread this path, creating the potential for serious conflict.

The coffee quota system was politically dominated by South American producers, but their traditionally close ties to the United States were under strain. The Americans were less able to support regional clients with resources and favours, which were also in demand elsewhere, putting erstwhile loyalties to the test. An overstretched United States, seeking to secure unhindered access to hitherto protected European colonial markets, was thus compelled to restrain Latin American producers from dumping their surpluses on world markets. At least in this respect, American policy was one of benign regulatory imperialism ${ }^{86}$ during a fragile period of global transition. Former American clients in Latin America held the potential to destabilize European decolonization and undermine America's global ascendancy. In this sense, the International Coffee Organization (I.C.O.) and the International Coffee Agreement (I.C.A.) were instrumental to the American aim to stabilize market conditions.

\footnotetext{
84 E.A.S. 5th November 1962: 'Kenya coffee losing flavour'.

${ }^{85}$ Michael Barratt Brown, The Economics of Imperialism, Middlesex UK: Penguin, 1974, pp. 208-9; Leo Panitch and Sam Gindin, 'Global Capitalism and the American Empire', in Leo Panitch and Colin Leys [eds.] The New Imperial Challenge, Socialist Register 2004, p.16.

86 Panitch and Gindin, 'Global Capitalism and the American Empire', pp.13-18.
} 
In particular, Brazil's relationship with the USA played a key part in reconfiguring and managing the economic environment between the advanced capitalist countries and their former colonies, putting into place a new system of global relationships under American hegemony. Brazil accounted for about $50 \%$ of world coffee production, and was acutely affected by declining prices, which by 1962 had fallen on average to half of their 1954 levels. Its shortage of foreign exchange reinforced subordinate ties to the United States. In an attempt to rescue its export earnings and the long-term future of its principal economic sector, Brazil orchestrated various quota agreements initiated by the United States, and the producers' alliance that became the I.C.O. This made Brazil seem overbearing within the I.C.O. as it faced accusations of securing its position at the expense of other producers. Overall, Brazil's dominant, and decidedly sub-imperial, role at the apex of the I.C.O. enabled it to influence the pattern of income redistribution from the advanced industrialized coffee consuming countries to the poor developing coffee producing countries. ${ }^{87}$ Superintended by the USA, Brazil thus played a pivotal role as an articulating joint in reshaping the economic environment for decolonization.

Short-term, annually renewable quota agreements were replaced by the I.C.A., which brought together both exporting and importing countries, and came into operation from July $1^{\text {st }}$ 1963, joining already existing agreements for olive oil, sugar, and wheat. ${ }^{88}$ As for the I.C.O., it was established in 1963, following a conference convened by the United Nations. Its goals were to institutionalize and internationalize the structures of management and the control of coffee marketing and production that accompanied the I.C.A., to assure permanence to its regulation, to iron out expected cyclical fluctuations, and to allay the recurrent crisis tendencies in the world market. The I.C.A.'s stated objectives were to ensure 'long-term equilibrium' between production and consumption, to mitigate the 'serious hardship' caused by surpluses, to lessen 'excessive fluctuations' in coffee prices, and to facilitate the increased purchasing power of exporting countries by keeping prices at 'equitable levels'. The I.C.A. stressed its development lode-star of increasing the productive resources of member states on the basis of a stable relationship between the trade in coffee and markets for industrial products. ${ }^{89}$

\footnotetext{
${ }^{87}$ Bilder, ‘The International Coffee Agreement: A Case History in Negotiation', p.329.

88 ibid.

${ }^{89}$ International Coffee Agreement, 1962; Chapter I, Article 1. p. 7.
} 
Overall, the I.C.A., which was renewed in 1968, aimed to reduce and limit competition by setting quota restrictions on signatory countries, thus minimizing the consequences of overproduction and low prices. The agreement meant that most producing and consuming countries became signatories to a commonly binding undertaking, whereby a target price, or price band, for coffee was set, and export quotas were allocated to each producer. The international coffee market was subjected to a regulatory control mechanism, so that when the indicator price calculated by the I.C.O. rose over the set price, quotas were relaxed. When it fell below the set price, quotas were tightened. If prices rose particularly sharply, quotas were to be abandoned until prices declined to within the band. ${ }^{90}$ This was therefore an export quota agreement, which supported prices by limiting the exports of each member. Another possible model was the multilateral contract, such as the Wheat Agreement, in which prices were supported within an agreed range through an undertaking by exporters to sell given amounts to importers at not more than a specified ceiling price, and an undertaking by importers to buy given amounts from exporters at not less than a specified floor price. The Tin Agreement followed yet another model, that of the buffer stock, in which prices were supported within an agreed range through the operations of an international buffer stock, which entered the market as the commodity was bought and sold at specified floor and ceiling prices. ${ }^{91}$

Far from alleviating tensions, however, the coffee quota system exacerbated and intensified already existing contradictions. The I.C.A. system was beset with squabbles ${ }^{92}$ over quotas from the start, and the growth of non-quota markets threatened to undermine the agreement altogether. There was an increasing volume of 'tourist' coffee, that is coffee exported, or stated to be exported, from a country other than its real place of production. ${ }^{93}$ In an attempt to overcome this, the International Coffee Council agreed in 1966 to issue stamps and certificates of origin, and to impose severe restrictions on imports from non-members. As for the I.C.O., while it gave the appearance of unity and cohesion, it would be a mistake to see its emergence as a sign that the global industry was becoming more organized. Nor did it represent a coalition of Third World producers attempting to equalize trading relationships with erstwhile imperial powers, although in some instances this did surface as a byproduct of

\footnotetext{
90 Daviron and Ponte, The Coffee Paradox, p.87; see also A.Kumar, Primary Commodities: International Control of Production and Trade, Ljubljana: Research Centre for Cooperation with Developing Countries [1986], p.165.

91 Bilder, 'The International Coffee Agreement: A Case History in Negotiation', p.329.

92 Bilder, 'The International Coffee Agreement: A Case History in Negotiation', p.340.

93 Daviron and Ponte, The Coffee Paradox, p.87.
} 
its role. The I.C.O. was alleged to favour the principal producers, as manifested in decisions concerning the distribution of estimated portions of a contracting market during a period of low prices. The ensuing rivalries, brought on as large numbers of producers sought to offload their surpluses, gave rise to unbearable strains, which had the potential to devastate the I.C.O.

Beneath the surface, the I.C.O. was decidedly hierarchical, with economic power highly concentrated into the hands of a few powerful producers, who could hold less significant producers to ransom, and ultimately to ruin them. Above all, the very structure of the I.C.O. assured the mutually antagonistic interdependence of all its separate parts. In all its essential decisions, the organization was accused of bowing to the superior weight of the leading producers, and of working to secure their interests by disciplining the smaller producers in Africa and Central America. Quotas allegedly enabled the larger and politically more powerful producers to protect and expand their markets at the expense of weaker rivals. The I.C.O. donned the garb of 'organized capitalism' in its modus operandi, keeping internecine struggles amongst global producers within the boundaries of order, so that the unfettered market anarchy of the 1930s appeared to have been overcome. However, the I.C.A. reinstated a variant of protectionism, which had characterized the inter-war period. National antagonisms reemerged, as agreements to police and discipline rivalries between member states were seen as tending to give the greatest advantage and flexibility to the leading producers, notably Brazil and Columbia. ${ }^{94}$

\section{Quotas and the straitjacket of national production}

Once the problems of overproduction and cumulative surpluses had been addressed within the I.C.A., the remaining problems of implementation were forced more and more into what became national straitjackets. In Kenya, this led to a problematic restructuring and the further displacement of settlers from the industry. The global crisis was passed onto the colonial and post independence governments to deal with, who prescribed the C.B.K. in a wider role of policing quotas ${ }^{95}$ and enforcing restrictions on planting. ${ }^{96}$ As this prevented additional acreage

\footnotetext{
${ }^{94}$ Bilder, 'The International Coffee Agreement: A Case History in Negotiation', pp.344-7.

${ }_{95}$ Government of Kenya, Development Plan 1966-70, Nairobi: Government Printer, 1966, p. 176.
} 
coming into bearing, the development problem of Kenya's coffee industry became not one of expanded production, but of careful limitation and quality control. This disabled coffee's prescribed role as a 'development' crop, as envisaged by the Swynnerton Plan, undermining the long-term policy of encouraging farmers to plant more coffee ${ }^{97}$ Expanded coffee planting was more or less banned until the mid-1970s, when world prices rose again. ${ }^{98}$

After Kenya had signed up to the I.C.A., the government stress on increasing productivity and output became less evident. However, the incidence of Coffee Berry Disease (C.B.D.), which increased during the 1960s, led to periodic falls in production, giving rise to a need to increase total output. During 1964-65, the season's crop totaled just 38,000 tons, against an estimate of 45,000 tons. The C.B.K. identified the impact of disease, heavy taxation, drought, and a low rate of profit as the 'serious problems' facing growers, 'leading some to uproot their crops'. Large numbers of African smallholders on the upper slopes of the Aberdares and Mount Kenya, where C.B.D. was most prevalent, uprooted their trees and opted for tea cultivation, a trend also influenced by their disillusionment with the co-operative societies over low and infrequent payments. ${ }^{99}$ Given the government's recurrent emphasis on quality, the deductions bearing down on the industry contributed to a marked reduction in the general quality of Kenya coffee. This was brought about by a lack of funds to carry out necessary tasks such as fertilizing and spraying, with growers penalized by the generalized refusal of banks to raise their overdraft limits. This in turn left the crop more vulnerable to drought and the recurrent ravages of disease, resulting in some areas in losses of $35-40 \%$.

A range of financial impositions, which had weighed heavily on European growers from the mid-1950s, now came to exert an unrelenting pressure on African farmers, despite their much lower production outlays. These included transportation costs, the C.B.K. levy, I.C.O. contributions, 'a very heavy export tax' and C.M.B. fees for warehousing, insurance, brokerage, packing and marketing expenses. There was also an agent's commission to the Kenya Planters Cooperative Union (K.C.P.U.), with its monopoly over milling, liquoring and storage. When the

\footnotetext{
${ }^{96}$ Kumar, Primary Commodities, p.165.

97 Swynnerton, A Plan.

${ }_{98}$ Heyer et al., Rural Development, p. 104; David Wall, 'Export Prospects for Africa South of the Sahara', African Affairs, 68:270, 1969, pp.26-41; Ann Seidman,'Prospects for Africa's Exports,' The Journal of Modern African Studies, 9, 3, 1971, pp. 409-428.

${ }_{99}$ C.B.K./Kenya Coffee, Bulletin, January 1966.
} 
C.M.B. was instructed by the government to levy an additional 3\% tax on coffee receipts for county council finances, widespread discontent erupted amongst growers. Strong opposition to cess payments was voiced from amongst delegates representing 100,000 mostly small scale African coffee farmers attending the K.C.P.U. conference in 1965, who expressed serious concern that cess deductions would imperil their slender profit margins and 'cause a reduction in quantity and quality.' The conference appointed a committee to approach the government and 'to protest at the cess on an already overburdened industry....'. ${ }^{100}$ This protest followed resolutions before the annual Nairobi coffee conference in January 1965, from mostly European farmers in Kiambu, Thika, Kabete and Ruiru, which deplored the imposition of extra cess payments. Thika's growers protested at an 'intolerable burden on an industry already penalised by selective taxation which will act as a deterrent to the efficient high acre yield farmers', whilst planters in Kabete were indignant that 'cess is discriminatory, unjust and economically unsound.' ${ }^{101}$ The Kiambu delegates implored the C.B.K. to align cess payments on the normal rating method based on land values and improvements. The conference released a statement warning that further deductions from the industry's account would make its situation 'precarious if the world price of our coffee drops'. ${ }^{102}$

Constrained by the I.C.A., the government was unable to alleviate the deductions on the industry as it pushed to raise the traditionally high quality of Kenya coffee even further, in order to gain the best possible return on a fixed tonnage. As in the past, the target was the niche market for high quality Arabicas. ${ }^{103}$ These necessities were dictated by an industry caught between a rock and hard place. If Kenya violated the terms of the I.C.A., it would lay itself open to penalties and risk a quota reduction. Alternatively, whilst coffee surpluses could be offloaded in non-quota markets, this would be at prices that were, at best, 30\% below quota market levels. The Department of Agriculture thus believed that Kenya's interests were 'best served by keeping the non-quota surplus as small as possible, while at the same time

\footnotetext{
${ }^{100}$ E.A.S. 12th November 1965: 'Coffee growers form committee to fight cess'.

${ }^{101}$ E.A.S. 12th January 1965: 'Opposition to cess on coffee'.

102 ibid.

${ }^{103}$ Alan Rufus Waters, 'Change and Evolution in the Structure of the Kenya Coffee Industry', African Affairs, 71: 283, 1972, pp. 163-175.
} 
controlling and upgrading cherry quality to preserve the domination by Kenya's Arabica of the lucrative mild coffee market.' ${ }^{104}$

Initially, African coffee planting standards were carefully controlled by the Department of Agriculture, but the control system broke down completely in the planting rush of 1963-4 to beat the looming I.C.A. restrictions. Consequent overproduction was the result of the extremely rapid expansion of African coffee growing which, as the planting rush came into bearing, approximately trebled by 1967 to 130,000 acres. ${ }^{105}$ Whilst land was taken out of production in the estate sector, with a decline from 80,118 acres to some 75,000 acres taking place during the course of 1965-7, the gains in African planted acreage amongst small scale farmers came to fruition and held fast. ${ }^{106}$ In 1966, new planting was limited to 'infills', where growers were allowed to buy seedlings to replace old or diseased trees up to $6 \%$ of their total stock, though this was cut to $2 \%$ the following year. Given these stringent prohibitions, the crux of the problem was enforcement. In 1966, the government established the Coffee Authority, charged with controlling and improving the coffee grown by African co-operative societies. This was followed by the imposition of tight checks and controls over nurseries and seedlings. Amongst the penalties dispensed were the uprooting of illegally planted coffee trees and the prosecution of growers. Significant uprooting of African coffee took place in Kisii, Murang'a and Kiambu, where thousands of trees on estate nurseries were burned. ${ }^{107}$

When Kenya joined the I.C.O. in 1966, following its earlier commitment as an I.C.A. signatory, the country's quota was increased to 43,970 tons. Nonetheless, production levels leapt to just under 55,000 tons, leaving some $20 \%$ of the entire output to chase sales on nonquota markets. The problems brought on by this excess were compounded when Kenya's quota for the following year was adjusted downwards to 41,085 tons. ${ }^{108}$ Competition from other producing countries for non-quota markets was intensifying, and Kenya was unable to rely on them to absorb its rising surplus. The trend towards overproduction looked set to continue, as

\footnotetext{
${ }_{104}$ Government of Kenya, Development Plan 1966-70, Nairobi: Government Printer, 1966, p.1.

105 P.R.O./C.O./544/ Department of Agriculture Annual Reports, 1962-8; Hyde, 'Plantation Struggles in Kenya', Appendix 36, p.304.

106 P.R.O./C.O./544/ Department of Agriculture Annual Reports, 1966-8.

107 K.N.A. Department of Agriculture Press statement, 4th June, 1967; C.B.K./Kenya Coffee, C.B.K. Monthly Bulletins, November 1966-June 1967. See also Lamb, Peasant Politics.

108 C.B.K./Kenya Coffee, March 1967, p. 92.
} 
African growers planted out expanded acreage under coffee in response to eased restrictions. The C.M.B. anticipated a rise in production to 70,000 tons, and warned that by 1968-9, even with an increased I.C.A. quota, 'a substantial quantity would be unsaleable overseas.' 109

\section{Conclusion}

The crisis developing within Kenya's agricultural economy from the mid-1950s reflected a profound upheaval in the world coffee market. A disequilibrium between production and consumption lay at the root of this crisis, creating pervasive conditions of flagging accumulation amongst producers. Faced with this situation, the colonial government's strategy, prior to joining the I.C.A., was to export the maximum amount of premium grade coffee to earn badly needed hard currency. While low prices mercilessly cut into profit margins, the Minister of Agriculture, Michael Blundell, believed that by selling more coffee at depressed prices Kenyan growers could conceivably compensate for losses. It was these considerations that lay at the source of Blundell's seemingly paradoxical recommendation to Kenya's coffee farmers to step up production during a prolonged period of contraction, even though this policy risked causing even greater price falls and set Kenya on a collision course with countries advocating quota pacts.

Under the adverse market conditions of the period, the average price of Kenya's Arabica was close enough to its costs of production to put the future of the settler sector at risk. Larger planters were those most likely to survive the enforced transformation of the industry, whilst others were too strapped for cash to stay the course. The weaker layers of European coffee capital were unable to marshal the necessary resources to restructure their businesses, and thus to come through a prolonged period of low prices. The plantation companies were able to tough out these conditions and save themselves through efficiencies and larger economies of scale. The introduction of new technology was evident amongst some better-placed planters, but this made large increases in output necessary to fund new investments.

${ }^{109}$ E.A.S. 17th November 1965: 'Kenya coffee crop facing surplus'. 
In a bid to restore the conditions for profitability across the coffee sector as a whole, and driven by the need to preserve its tax base, the colonial government responded to the reverberations of the world market by opening the doors to small scale African farmers, lifting the remaining restrictions on Arabica coffee production, previously the exclusive preserve of European settlers. Africans were beckoned into a crisis-ridden industry, hemmed in by quotas and falling prices, with increasing amounts of coffee being diverted into non-quota markets at even lower prices. Overall, the issue at stake was the extended reproduction of capital. It was here that the solution of low cost African coffee farmers came into its own, though at the expense of displacing many settlers out of the sector. The much lower labour costs of African farmers were attributable to their ownership of land and crops, longer working days, more intense working patterns and an ability to mobilize the labour power of the extended family for a small return. This made them better able to bear the burdens of global competition, and, aided by the colonial government, they soon threatened to usurp the pre-eminent position of European farmers. Overseas competition and growing African coffee production acted in tandem to devalue settler capital, pulling down the average rate of profit below what European growers could bear. ${ }^{110}$

Abroad, the continuing prospect of the large Latin American producers releasing their surpluses onto the world market threatened a global depreciation of coffee capital. Overall, the harsh necessities of the world market dictated the adjustments to be adopted. These were enforced through the mechanisms of the I.C.A. and the I.C.O., initiated by the USA, and exercising considerable control over the relationship between the production and circulation of the coffee commodity. The expanded reproduction of coffee capital was premised on sustaining the rate and mass of profit within the industry, a necessity which pressed up against the limits imposed by international agreements. Vast surpluses of coffee were withheld from the sphere of circulation by strict quotas, and were thus unable to undergo the metamorphosis into money and capital. ${ }^{111}$ The crisis potential of this situation lay in the increasing separation between production and sale, a tendency that undermined the velocity of circulation and slowed down payments to growers. This created a dysfunctional circuit of accumulation, which endangered

\footnotetext{
${ }^{110}$ For the average rate of profit, see K. Marx, Capital Volume 3, part 2, 'Conversion of Profit into Average Profit,' Moscow : Progress Publishers, 1971, pp.142-210.

${ }^{111}$ K.Marx, Capital Volume 1, Chapter 3 'Money, or the Circulation of Commodities,' Moscow: Progress Publishers, 1959, pp.97-144.
} 
the reproduction of coffee capital. Beyond fulfilling quotas, non-quota markets were the only route for absorbing surpluses, though even they were showing perilous signs of saturation. The compelling motive for all was the self-expansion of capital, but, under conditions where rising amounts of coffee lay unsold, this caused intense conflicts between rival producers.

The I.C.O. attempted to defuse these tensions through a web of international procedure. ${ }^{112}$ Beneath the I.C.O. veil of equality, however, coffee producers waged an undeclared trade war to gain larger quotas for themselves. In this struggle, a few oligopsonistic producer states moved to reduce the competition of their rivals, and even threatened to eliminate them. In this crisis, the I.C.O.'s decisions carried great weight in deciding the extent and tempo of growth of those countries that depended on coffee to generate the capital resources for their general development, especially those African states that had recently gained their independence and were under pressure to deliver promissory notes.

A common misperception pits Latin Americans versus Africans as rivals in the world coffee market, but further investigation reveals that the principal antagonisms were more deeply rooted in the different sizes of producers, both internationally and internally. Within the producing countries themselves, global rivalries were an essential source of the ongoing tensions between plantation and smallholder coffee, which showed themselves most sharply around the issues of economies of scale, production organization, quality control, and labour costs. Internal changes and dynamics were inextricably linked to fluctuations within the world coffee market, and the interrelationships between constituent producers, in a changing context of either unregulated or rule-bound competitive environments. The issue of quality became a paramount concern at crisis points, especially the late 1950s and early 1960s, when the global commodity chain was in danger of breaking down altogether.

The Kenyan case provides a point of departure for what it reveals about the broader themes and issues in the global history of the coffee commodity. This article has shown how a small, specialist producer of high-quality Arabica coffee responded to the crisis-ridden global market of the late 1950s and early 1960s, through examining the globally induced tensions and conflicts between the state, European coffee planters, and small scale farmers. The crisis paroxysms of

${ }_{112}$ Bilder, 'The International Coffee Agreement: A Case History in Negotiation', pp.328-91. 
this period could not but richly inform the framework and development outcomes of Kenya's independence in 1963. However, the changing relationships and restructuring within Kenya's coffee industry brought on by these cycles were hardly unique. Comparable changes occurred in Uganda, Tanganyika, Costa Rica, El Salvador and Guatemala. All of these producers had to negotiate their way through the troubled years after 1955, and, in particular, complained about the 'straitjacket of national production' enforced by quotas imposed by the International Coffee Organisation which was dominated by the largest producers. This article has examined how Kenya navigated this crisis during a crucial period of colonial war and decolonization, which made its responses idiosyncratic in some ways. However, much of what happened in Kenya also characterised hard pressed smaller coffee producers elsewhere, as in Guatemala, where a largely Europeanized elite struggled to compete with indigenous smallholders.

David Hyde is Lecturer in Development Studies at the University of East London. He studied at S.O.A.S. and was Henry Chapman Fellow at the Institute of Commonwealth Studies. He specializes in Africa's development and labour issues in Kenya. 